Journal of Scientific Perspectives

Volume 3, Issue 3, Year 2019, pp. 245-252

E - ISSN: 2587-3008

URL: http://ratingacademy.com.tr/ojs/index.php/jsp

DOI: https://doi.org/10.26900/jsp.3.026

Research Article

\title{
REMOVAL OF THORIUM (IV) ION BY USING MODIFIED CYSTOSEIRA BARBATA
}

\author{
Yeliz OZUDOGRU * \\ * Assist. Prof. Dr., Çanakkale Onsekiz Mart University, Faculty of Education, Department of \\ Chemistry Education, TURKEY, e-mail: yelizozudogru@ hotmail.com \\ ORCID ID: https://orcid.org/0000-0003-0471-6404
}

Received: 16 July 2019; Accepted: 25 July 2019

\begin{abstract}
In this work, it was tried to remove Th (IV) radioactive ions in aqueous solution by using modified Cystoseira barbata. $p H$, contact time, concentration effects and temperature were investigated. It was observed that the amount of the removal was not affected by $\mathrm{pH}$ change. Adsorption isotherm models were applied and the maximum qm value was found to be $116.95 \mathrm{mgg}-1$ at 250C.
\end{abstract}

Keywords: Th, biosorption, Cystoseira barbata 


\section{INTRODUCTION}

Water pollution from industrial wastes and environmental activities is increasing (Caparkaya and Cavas., 2008; El Jamal and Ncibi, 2012). One of the sources of water pollution is heavy metals. Heavy metals are toxic and have acquired fame among environmental contaminants (Moghaddam et al., 2013). Thorium is one of the most hazardous heavy metals for industrial applications and the environment (Khani et al., 2006; Riazi et al., 2016). It is used as a nuclear fuel at power plants and its compounds are used in the field of science of technology. (Riazi et al., 2014). If Th spreads through the environment, it can reach humans through the food chain and can cause damage in various organs of the human body. Therefore, it has become important to remove Th ions in aqueous solution in recent years (Aytas et al., 2014; Keshtkar et al., 2015; Riazi et al., 2016). Many techniques are used in order to remove Th ions which include precipitation, solvent extraction and adsorption. Of these techniques, the adsorption technique is widely preferred for it is simple, easily feasible and cost-effective (Kratochvil and Volesky, 1998; Pavasant et al., 2006; Zhou et al., 2016; Huang et al., 2018). Algae have been found to be potentional biosorbents (McMullan et al., 2001; Abd-El Kareem and Taha, 2012) for their functional groups (Ariff et al., 1999; Davis at al., 2003; Lodeiro et al., 2006; Vieira and Volesky, 2010). Especially brown algaes have been great adsorption capacities among other algaes, because of alginates (Malik et al., 1999; Schiewer and Wong, 2000). In recent years, many successful separation operations have been carried out for radionuclides. There are many studies conducted on removal of Th ion from aqueous solution (Yang and Volesky, 1999; Picardo et al., 2006; Ghasemi et al., 2011; Cecal et al., 2012; Keshtkar and Hassani, 2014; Riazi et al., 2016; Kaynar and Sabikoglu, 2018). Factors such as, temperature, $\mathrm{pH}$, contact time were affected the adsorption capacities (Vijayaraghavan and Yun, 2008). In addition, in some studies, it has been seen that pre-concentration with different chemicals increases the adsorption capacity (Bai et al., 2010).

In this study, it attempted to remove Th ion in the aqueous solution by using Cystoseira barbata, one of the brown algae, pre-concentrated with $\mathrm{HNO}_{3}$. Studies on $\mathrm{pH}$ effect, time, concentration, temperature and desorption were conducted.

\section{MATERIAL AND METHODS}

\subsection{Preparation of the adsorbent}

The adsorbent was the alga $C$. barbata (Stackhouse) C. Agardh was collected from the Dardanos Campus of Canakkale Onsekiz Mart University. The biomass was washed at distilled water and dried in an oven at $60^{\circ} \mathrm{C}$ until constant weight was reached. The biomass was chemically modified by $0.1 \mathrm{M} \mathrm{HNO}_{3}$.

\section{Pre-treatment with $\mathrm{HNO}_{3}$}

A sample of $2.5 \mathrm{~g}$ of dries biomass was treated with $25 \mathrm{ml}$ of $0.1 \mathrm{M} \mathrm{HNO}_{3}$. The mixture was shaken for 3 hour on a shaker at $250 \mathrm{rpm}$ at room temperature. The biomass was then filtered off, followed by washing with deionized and it was then dried in an oven at $60^{\circ} \mathrm{C}$ for 24h. This was a modification of the pre-treatment performed by Rubin et al, 2005.

\subsection{Reagent and equipment}

In this study all chemicals were used analytical grade (Merck). Distilled water was used to prepare all solutions. Stock solution of Th (IV) $(1000 \mathrm{ppm})$ were prepared by $\mathrm{Th}\left(\mathrm{NO}_{3}\right)_{4}$. The concentration of Th (IV) ion in the filtered samples was measured with Rayleigh Vis-7220G spectrophotometer at $667 \mathrm{~nm}$. The $\mathrm{pH}$ adjustments were performed using $0.1 \mathrm{M} \mathrm{HCl}$ or $0.1 \mathrm{M}$ $\mathrm{NaOH}$. Samples were filtered with a Millipore Millex-HV hydrophilic PVDF $0.45 \mu \mathrm{m}$ syringe filter. A Wise Bath WSB-30 model shaker was used for the experiments. The Fourier Transform 
infrared spectroscopy (FTIR) analysis was completed using a Perkin Elmer Spectrum BX-11 Model FTIR spectrophotometer.

\subsection{Batch biosorption studies}

Five $\mathrm{pH}$ values $(2,3,5,7$ and 9$)$ were tested in the trials. Accordingly, $100 \mathrm{mg}$ biomass was put into the Falcon tubes filled with $10 \mathrm{ppm} 10 \mathrm{ml}$. Th (IV) ion solutions at different $\mathrm{pH}$ values. The tubes were shaken at room temperature for $60 \mathrm{~min}$ at $250 \mathrm{rpm}$. After adsorption step supernatant is taken out by a syringe.

The adsorbance of value of the supernatant was measured with the spectrophotometer and the amount of adsorbed Th (IV) ion solution was calculated. The percentage of Th (IV) ion removal (R) from the aqueous solution was calculated as follows:

$$
\% \text { Removal }=\frac{C_{o}-C_{e}}{C_{o}} * 100
$$

Where $C_{o}$ is the initial Th (IV) concentration $\left(\mathrm{mgL}^{-1}\right)$ and $C_{e}$ is the adsorbed Th (IV) concentration $\left(\mathrm{mgL}^{-1}\right)$

For determination of $\mathrm{pH}$ experiments, different time intervals $(10,25,45,60,80,100$, $150,200,300$ and $400 \mathrm{~min}$ ) were applied in room temperature at $250 \mathrm{rpm}$. The amount of radioactive ion uptake, $\mathrm{q}_{\mathrm{t}}\left(\mathrm{mgg}^{-1}\right)$, at each interval was calculated using the following equation:

$$
q_{t}=\frac{\left(C_{\mathrm{o}}-C_{e}\right)}{M} * V
$$

Where $C_{o}$ is the initial Th (IV) ion concentration $\left(\mathrm{mgL}^{-1}\right), C_{e}$ is the concentration of Th (IV) ion concentration at a given time $\left(\mathrm{mgL}^{-1}\right), \mathrm{V}$ is the volume of radioactive solution $(\mathrm{L})$ and $\mathrm{M}$ is the mass of biosorbent ( $\mathrm{g}$ ) (dry weight).

The batch adsorption technique was used for sorption. $100 \mathrm{mg} \mathrm{C}$. barbata was put into a falcon tubes and treated with $10 \mathrm{~mL}$ of Th(IV) solution at different concentration (5-10-2050-100-150-200-300-350-400-450 and 500 $\mathrm{mgL}^{-1}$ ). The Falcon tubes were shaken at $250 \mathrm{rpm}$ at $25^{\circ} \mathrm{C}$ and $45^{\circ} \mathrm{C}$. Then samples were filtered with a syringe filter and the adsorbed amount of Th(IV) ions were measured using spectrophotometer.

The equilibrium data at different temperatures were analyzed with Langmuir and Freundlich isotherms. The Langmuir model was shown below (Langmuir, 1918):

$$
\frac{C_{e}}{q_{e}}=\frac{1}{q_{m} a_{L}}+\frac{C_{e}}{q_{m}}
$$

Where $q_{e},\left(\mathrm{mgg}^{-1}\right)$ is the amount of $\mathrm{Th}(\mathrm{IV})$ ions, $C_{e}\left(\mathrm{mgL}^{-1}\right)$ is the equilibrium concentration of the Th (IV) ions, $q_{m}\left(\mathrm{mgg}^{-1}\right)$ is the maximum adsorption capacity and $a_{L}$ is the Langmuir constant related to the energy of adsorption.

A linear form of the Freundlich equation is shown below (Freundlich, 1906):

$$
\log q_{e}=\log K_{f}+1 / n_{f} \log C_{e}
$$

Where $K_{f}\left(\mathrm{mgg}^{-1}\right)$ is related to adsorption capacity and $n_{f}$ is an empirical parameter that varies with degree of heterogeneity. 


\section{RESULTS AND DISCUSSION}

\subsection{Determination of optimum $\mathbf{p H}$}

$\mathrm{pH}$ is one of the most important effects that have an impact upon the biosorption. In order to examine $\mathrm{pH}$ that affects biosorption, $\mathrm{pH}$ trials at different values were undertaken. Results are given in Figure 1. It was observed that Th adsorption \% values remained unaffected by $\mathrm{pH}$ change. When looking at overall $\mathrm{pH}$ values subject to the study, it was ascertained that $\mathrm{pH}$ does not have much effect and adsorption over $96.5 \%$ was observed.

\subsection{Determination of Optimum Contact Time}

During equilibrium trials, trials were conducted for different times with a view to examining the effect of the time. Results are given in Figure 2. According to results obtained, it was observed that the system reached equilibrium in the first 100 minutes.

Figure 1. Effect of $\mathrm{pH}$ on the biosorption of Th (IV)

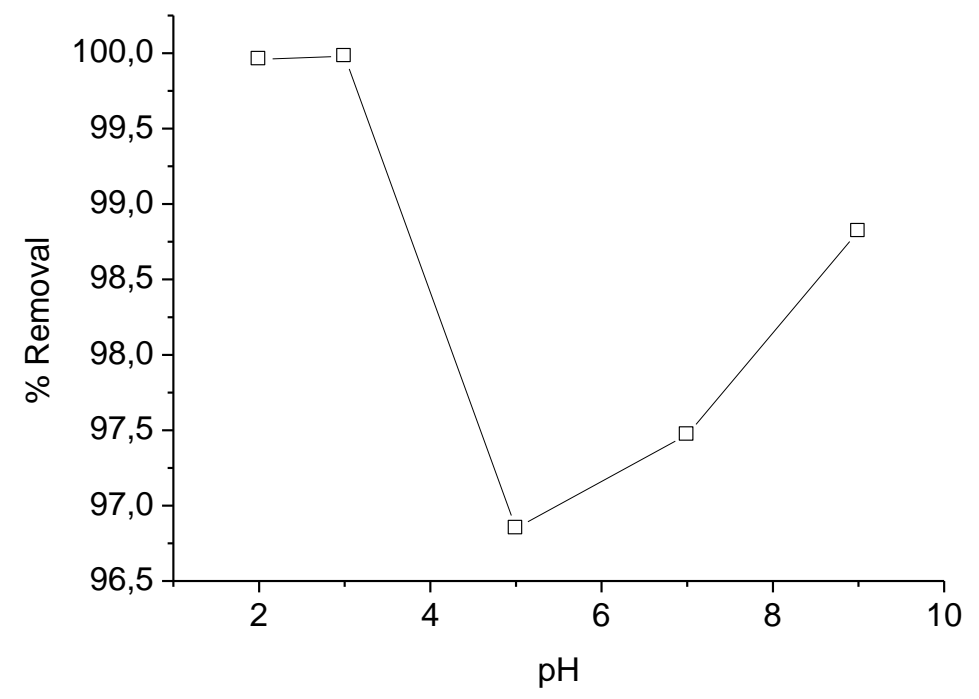

Figure 2. Effect of contact time on the biosorption of Th (IV)

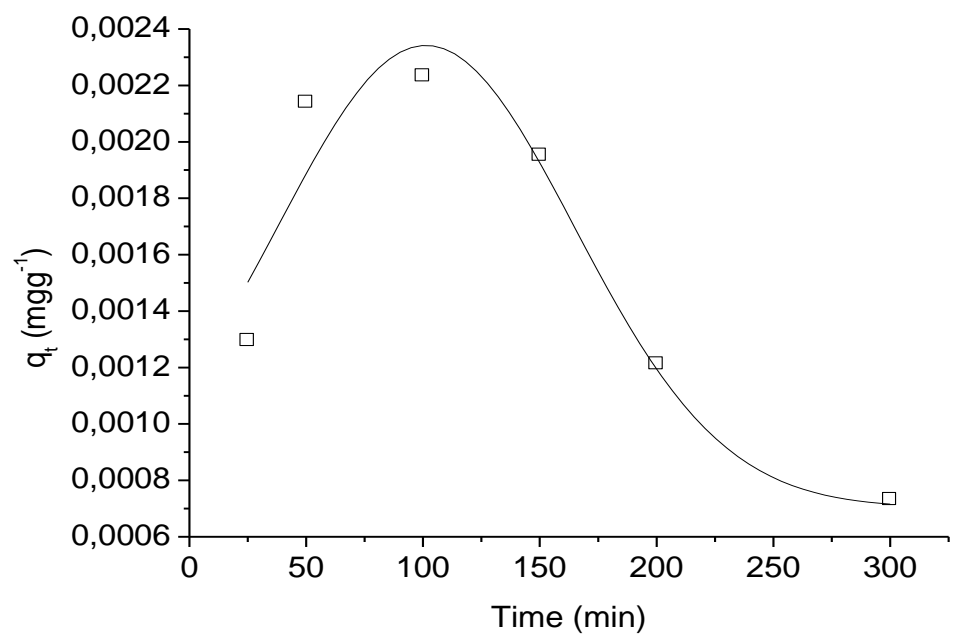




\subsection{Adsorption isotherms}

Isotherm studies were conducted on Th (IV) ions at different temperatures. Table 1 shows Langmuir and Freundlich isotherm parameters. It was observed that, at $25^{\circ} \mathrm{C}$, Langmuir isotherm model adapted better. At $25^{\circ} \mathrm{C}$, de $\mathrm{q}_{\mathrm{m}}$ value was $116.96 \mathrm{mgg}^{-1}$ and $92.94 \mathrm{mgg}^{-1}$ at $45^{\circ} \mathrm{C}$. According to results, it was observed that $\mathrm{q}_{\mathrm{m}}$ value decreased as the temperature increased.

Table 1. Langmuir and Freundlich isotherm models of $C$. barbata for Th (IV) ion at different temperatures

\begin{tabular}{|l|c|c|c|c|c|c|c|}
\hline & & \multicolumn{4}{|c|}{ Langmuir isotherm models } & \multicolumn{3}{|c|}{ Freundlich isotherm models } \\
\hline & $\begin{array}{c}\text { Temperature } \\
\left({ }^{\circ} \mathrm{C}\right)\end{array}$ & $q_{m}\left(\mathrm{mgg}^{-1}\right)$ & $a_{L}$ & $R_{L}{ }^{2}$ & $n_{f}$ & $K_{f}\left(\mathrm{mgg}^{-1}\right)$ & $R_{F}{ }^{2}$ \\
\hline $\begin{array}{l}0.1 \mathrm{M} \mathrm{HNO}_{3} \\
\text { C. } \text { barbata }\end{array}$ & 25 & 116.96 & 21.08 & 0.9537 & 1.13 & 1.893 & 0.9009 \\
\hline $\begin{array}{l}0.1 \mathrm{M} \mathrm{HNO}_{3} \\
\text { C. barbata }\end{array}$ & 45 & 92.94 & 27.20 & 0.9108 & 0.49 & 106.836 & 0.9182 \\
\hline
\end{tabular}

Table 2 shows maximum Th (IV) ion adsorption capacities of different adsorbents. According to results, it was established that modification of $C$. barbata caused an increase in adsorption capacity $\left(\mathrm{q}_{\max }\right)$. It was observed that the modified $C$. barbata has a high $\mathrm{q}_{\mathrm{m}}$ value.

Table 2. Maximum Th (IV) ion adsorption capacities of different adsorbents

\begin{tabular}{|l|l|l|}
\hline Biyomas & $\mathrm{q}_{\max }(\mathrm{mg} / \mathrm{g})$ & Referance \\
\hline Rhizopus arrhizus & 238.1 & Abbasizadeh et al.,(2013) \\
\hline Cystoseiraindica & 169.49 & Keshar and Hassani (2014) \\
\hline Aspergillus niger & 22 & Tsezos and Volesky (1981) \\
\hline $\begin{array}{l}\text { Cystoseira indica } \\
\text { (pretreated } \mathrm{CaCl}_{2} \text { ) }\end{array}$ & 195.7 & Riazi et al., 2014 \\
\hline Cystoseira barbata & 39.45 & Ozudogru (2019) \\
\hline $\begin{array}{l}\text { Cystoseira barbata } \\
\text { (with modified) }\end{array}$ & $\begin{array}{l}116.96\left(25^{\circ} \mathrm{C}\right) \\
92.94\left(45^{\circ} \mathrm{C}\right)\end{array}$ & This study \\
\hline
\end{tabular}

\subsection{Desorption study}

For desorption studies of Th (IV) ion, trials were conducted with different times and different eluents. Results obtained are given in Table 3. $1 \mathrm{M} \mathrm{HNO}_{3}$ was found to be the best chemical for 30 minutes $(99.60 \%)$. It was found to be $93.34 \%$ at 10 minutes for $0.5 \mathrm{M} \mathrm{HNO}_{3}$.

Table 3. Desorption of Th (IV) ion by different eluents

\begin{tabular}{|l|l|l|l|}
\hline $\begin{array}{l}\text { Biomass } \\
0.1 \mathrm{M} \mathrm{HNO}_{3} \text { C. barbata }\end{array}$ & Eluent & Time (min.) & $\begin{array}{l}\text { \% Removal of } \\
\text { Th (IV) ions }\end{array}$ \\
\hline \multirow{5}{*}{} & $0.5 \mathrm{M} \mathrm{HNO}_{3}$ & 30 & 62.20 \\
\cline { 2 - 4 } & $1 \mathrm{M} \mathrm{HNO}_{3}$ & 30 & 99.60 \\
\cline { 2 - 4 } & $0.5 \mathrm{M} \mathrm{HNO}_{3}$ & 20 & 74.56 \\
\cline { 2 - 4 } & $1 \mathrm{M} \mathrm{HNO}_{3}$ & 20 & 96.96 \\
\cline { 2 - 4 } & $0.5 \mathrm{M} \mathrm{HNO}_{3}$ & 10 & 93.34 \\
\cline { 2 - 4 } & $1 \mathrm{M} \mathrm{HNO}_{3}$ & 10 & 94.82 \\
\hline
\end{tabular}




\section{CONCLUSION}

In the present study, it was attempted to remove Th (IV) ion in the aqueous solution by using modified Cystoseira barbata. At each $\mathrm{pH}$ studied, it was observed that the biosorption capacity was over $96 \%$. Concentration trials were conducted at 2 different temperatures and the highest adsorption capacity was found to be $116.96 \mathrm{mgg}^{-1}$ at $25^{\circ} \mathrm{C}$. For recovery of the Th (IV) ion charged, it was ascertained that the most effective chemical was $1 \mathrm{M} \mathrm{HNO}_{3}(99.60 \%)$ at 30 minutes. Desorption studies showed that Th (IV) ion charged can be recovered. To conclude, modified $C$. barbata, a natural and environmentally friendly adsorbent, can be used for removal of Th (IV) ion in aqueous solution.

\section{Acknowledgements}

This study has been funded by Canakkale Onsekiz Mart University research foundation BAP (Project no: FBA-2016-968). I would like to thank Melek MERDIVAN and Tolga GÖKSAN for their help. 


\section{REFERENCES}

ABBASIZADEH, S., KESTHAR, A.R. and MOUSAVIAN, M.A., 2013, Preparation of a novel electrospun polyvinyl alcohol/titanium oxide nanofiber adsorbent modified with mercapto groups for uranium(VI) and thorium(IV) removal from aqueous solution, Chemical Engineering Journal, 220, 161-171.

ABD-EL-KAREEM, M. S., and TAHA, H. M., 2012, Decolorization of malachite green and methylene blue by two microalgal species, International Journal of Chemical and Environmental Engineering, 3(5): 297-302.

ARIFF, A.B., MEL, M., HASAN, M.A. and KARIM, M.I.A., 1999, The kinetics and mechanism of lead (II) biosorption by powderized Rhizopus oligosporus. World Journal of Microbiology and Biotechnology, 15(2) : 291-298.

AYTAS, S., GUNDUZ, E. and GOK, C., 2014, Biosorption of uranium ions by marine macroalga Padina pavonia, Clean Soil Air Water , 42 (4), 498-506.

BAI, J., YAO, H., FAN, F., LIN, M., ZHANG, L., DING, H., LEI,F., WU, X., LI, X., GUO, J. and QIN, Z., 2010, Biosorption of uranium by chemically modified Rhodotorula glutinis, Journal of Environmental Radioactivity, 101(11), 969-73.

CAPARKAYA, D. and CAVAS, L., 2008, Biosorption of methylene blue by a brown alga Cystoseira barbatula Kützing, Acta Chimica Slovenica, 55(3): 547-553.

CECAL, A., HUMELNICU, D., RUDIC, V., CEPOI, L., GANJU, D. and COJOCARI, A., 2012, Uptake of uranyl ions from uranium ores and sludges by means of Spirulina platensis, Porphyridium cruentum and Nostoklinckia alga, Bioresource Technology, 118, 19-23.

DAVIS, T.A., VOLESKY, B. and MUCCI, A., 2003, A review of the biochemistry of heavy metal biosorption by brown algae, Water Resource, 37: 4311-4330EL JAMAL, M. M. and NCIBI, M. C., 2012, Biosorption of methylene blue by Chaetophora elegans Algae: Kinetics, Equilibrium and Thermodynamic Studies, Acta Chimica Slovenica, 59(1): 24-31.

FREUNDLICH, H., 1906, Over The Adsorption in Solution, The Journal of Physical Chemistry, 57:385.

GHASEMI, M., KESHTKAR, A. R., DABBAGH, R. and JABER SAFDARI, S., 2011, Biosorption of uranium (VI) from aqueous solutions by Ca-pretreated Cystoseira indica alga: breakthrough curves studies and modeling, Journal of Hazardous Materials, 189(1-2), 141-9.

KESHTKAR, A.R. and HASSANI, M.A., 2014, Biosorption of thorium from aqueous solution by Capretreated brown algae Cystoseira indica, Korean Journal of Chemical Engineering, 31 (2): 289-295.

KESHTKAR, A.R., MOHAMMADI, M. and MOOSAVIAN, M.A., 2015, Equilibrium biosorption studies of wastewater $\mathrm{U}(\mathrm{VI}), \mathrm{Cu}(\mathrm{II})$ and $\mathrm{Ni}(\mathrm{II})$ by the brown alga Cystoseira indica in single, binary and ternary metal systems, Journal of Radio analytical and Nuclear Chemistry, 303, 363376.

KHANI, M. H., KESHTKAR, A. R., MEYSAMI, B., ZAREA, M.F. and JALALI, R,.2006, Biosorption of uranium from aqueous solutions by nonliving biomass of marine algae Cystoseria indica, Journal of Biotechnology, 9 (2),100-106.

HUANG, Y., HU, Y., CHEN, L., YANG, T., HUANG, H., SHI, R., LU, P. and ZHONG, C., 2018, Selective biosorption of thorium (IV) from aqueous solutions by ginkgo leaf, PlosOne, 13(3):125.

KAYNAR, U., H., ȘABİKOĞLU, İ., 2008, Adsorption of thorium by amorphous silica; response surface modeling and optimization, Journal of Radio analytical and Nuclear Chemistry, 318 (2): 823-834.

KRATOCHVIL, D. and VOLESKY, B., 1998, Biosorption of $\mathrm{Cu}$ from ferruginous wastewater by algal biomass, Water Research, 32(9): 2760-2768. 
LANGMUIR, I., 1918, The adsorption of gases on plane surfaces of glass, mica and platinum, Journal of American Chemical Society, 40: 1361-1403.

LODEIRO, P., BARRIADA, J.L., HERRERO, R. and SASTRE DE VINCENTE, M.E., 2006, The marine macroalga Cystoseira baccata as biosorbent for cadmium (II) and lead (II) removal: kinetic and equilibrium studies, Environmental Pollution, 142: 264-273.

MALIK, D. J., STREAT, M. and GREIG, J., 1999, Characterization and Evaluation of Seaweed-Based Sorbents for Treating Toxic Metal-Bearing Solutions, Process Safety and Environmental Protection, 77 (4): 227-233.

MC MUllan, G., MEEHAN, C., CONNEELY, A., KIRBY, N., ROBINSON, T., NIGAM, P., BANAT, I. M., MARCHANT, R. and SMYTHET, W. F., 2001, Microbial decolourisation and degradation of textile dyes, Applied Microbiology and Biotechnology, 56: 81-87.

MOGHADDAM, M. R., FATEMI, S. and KESHTKAR, A., 2013, Adsorption of lead $\left(\mathrm{Pb}^{2+}\right)$ and uranium cations by brown algae; experimental and thermodynamic modeling, Chemical Engineering Journal, 231, 294-303.

OZUDOGRU, Y., 2019, Cystoseira barbata ile toryum biyosorpsiyonu, Dokuz Eylül Üniversitesi Fen ve Mühendislik Dergisi, 21: 461-468.

PAVASANT, P., APIRATIKUL, R., SUNGKHUM, V., SUTHIPARINYANONT, P., WATTANACHIRA, S. and MARHABA, T. F., 2006, Biosorption of $\mathrm{Cu}^{2+}, \mathrm{Cd}^{2+}, \mathrm{Pb}^{2+}$ and $\mathrm{Zn}^{2+}$ using dried marine green macroalga Caulerpa lentillifera, Bioresource Technology, 97(18): 2321-2329.

PICARDO, M.C., DE MELO FERREIRA, A.C. and AUGUSTO DA COSTA, A.C., 2006, Biosorption of radioactive thorium by Sargassum filipendula, Applied Biochemistry and Biotechnology, 134: 193-206.

RIAZI, M., KESHTKAR, A.R. and MOOSAVIAN, M.A., 2014, Batch and continuous fixed-bed column biosorption of thorium (IV) from aqueous solutions: equilibrium and dynamic modeling, Journal of Radio analytical and Nuclear Chemistry, 301 (2) : 493-503.

RIAZI, M., KESHTAR , A.R. and MOOSAVAIAN, M.A. 2016. Biosorption of Th(IV) in a fixed-bed column by Ca-pretreated Cystoseira indica. Journal of Environmental Chemical Engineering, 4: 1890-1898.

RUBIN, E., RODRIGUEZ, P., HERRERO, R., CREMADES, J., BARBARA, I. and E SASTRE DE VICENTE, M., 2005, Removal of Methylene Blue from aqueous solutions using as biyosorbent Sargassum muticum: an invasive macroalga in Europe, Journal of Chemical Technology and Biotechnology, 80 (3): 291-298.

SCHIEWER, S. and WONG, M. H., 2000, Ionic strength effects in biosorption of metals by marine algae, Chemosphere, 41 (1-2): 271-282.

TSEZOS, M. and VOLESKY, B., 1981, Biosorption of uranium and thorium, Biotechnology and Bioengineering, 23, 583-604.

VIEIRA, R. H. S. F. and VOLESKY, B., 2010, Biosorption: a solution to pollution?, International Microbiology, 3: 17-24.

VIJAYARAGHAVAN, K. and YUN, Y. S., 2008, Bacterial biosorbents and biosorption, Biotechnology Advances, 26: 266-291.

YANG, J. and VOLESKY, B., 1999, Biosorption of uranium on Sargassum biomass, Water Research, $33: 3357-3363$.

ZHOU, L., WANG, Y., ZOU, H., LIANG, X., ZENG, K., LIU, Z. and ADESINA, A.A., 2016, Biosorption characteristics of uranium (VI) and thorium (IV) ions from aqueous solution using $\mathrm{CaCl}_{2-}$ modified Giant Kelp biomass, Journal of Radio analytical Nuclear Chemistry, 307: 635644. 